\title{
On the occasion of Wolfgang Schaper's 75th birthday
}

It is not easy to fully appreciate the achievements of Professor Dr. med. Dr. h.c. Wolfgang Schaper, which include his outstanding performance as a scientist at an international level, his leadership in the reorganization of the cardiovascular society in Germany in the 1970 s, and not to forget his function as director of the Max Planck Institute for Physiological and Clinical Research in Bad Nauheim starting in 1972.

Over a time span of 45 years, the focus of his scientific work was on the blood supply to the myocardium. Wolfgang Schaper started investigating collateral blood flow during ischemia already in the 1960s, when the existence of collateral vessels in the human myocardium - due to lack of angiography in many institutions - was still a matter of debate.

As a consequence, his research in the 1970s was dominated by studies on myocardial blood supply and myocardial cell death induced by myocardial infarction. In his laboratories, the method to sequentially measure blood flow by radioactive labeled microspheres during up to seven stages of ischemia or reperfusion was developed. The development of this technique gave him the unique opportunity to investigate the mechanisms of ischemic damage during vascular occlusion and reperfusion on the cellular and subcellular levels.

With a new focus on arteriogenesis, which reflects the growth of collateral arteries, mechanisms of endothelial function, the role of growth factors, and cell-cell interactions became the primary objects of his research. This shift in his research was associated with the necessity to convert major parts of a physiological laboratory into a research unit for cell biology. Relocation into a new research building came just in time for this conversion. From that point on, the interplay of nitric oxide, vascular endothelial growth factor (VEGF), endothelin, and other factors occupied the work force at the institute. During the 1980 s and thereafter the typical physiology laboratory was thereby converted into a "work bench", providing tissues and cells.

The next major step in his work was to investigate the molecular mechanism of arteriogenesis induced by shear stress. The induction of a specific gene expression pattern in growing collateral arteries, the signal transduction between endothelial and smooth muscle cells in association with the expression of certain growth factor receptors during collateral growth, were considered markers of arteriogenesis. Professor Schaper's continuing intensive occupation with arteriogenesis resulted in a permanent addition of advanced methods and research tools. His passion for continuing mental exercise allowed him to stay at the international forefront of the research community in his field. In this way, he added piece after piece to the puzzle, which now shows the picture of a pathway of arteriogenesis that is able to convert pre-existent collaterals into functional arteries.

Scientifically, he never grew old. This by no means says that he was always a part of the group of socalled opinion leaders. Sometimes, he was ahead of his time due to superior techniques as in the demonstration of collaterals in man, or of higher precision and less preoccupation by a hypothesis, "how it had to be", as in the border zone of myocardial infarction. $\mathrm{He}$ is remembered saying in a hall full of scientists, during the "hype" of VEGF as the answer to revascularization of ischemic myocardium: "VEGF induces the growth of vessels; however they are the wrong ones, they are not arterioles and they do not persist." There was no discussion, only dead silence after this talk at the American Heart Association (AHA) in 
Atlanta in 1999. Probably no one believed him. In the meantime, the VEGFs have found their place, however not as a magic drug for tissue revascularization after ischemic damage.

In 1975, Professor Schaper was elected Secretary General of the German Cardiac Society (GCS), then the "Deutsche Gesellschaft für Herz- und Kreislaufforschung", a position, which he held from 1976 until 1989. The GCS at that time was a very traditional, small society, devoted predominantly to the elite of basic science and pathological physiology. It was time for major changes: German cardiovascular medicine was slowly emerging from the post-war situation, which was characterized by severe personnel losses as a consequence of prosecution and fatalities during the war. A new generation of scientists was growing up, many returning from training abroad, equipped with new ideas, a wide horizon, and full of enthusiasm. These people needed an organization to identify with on a national level and national meetings that could serve as a platform to present their work.

This situation presented a veritable task for Professor Schaper. The society and at the same time the German Annual Meeting of Cardiology had to be converted into a modern format, where not only established scientists would discuss, but where also young researchers would have the possibility to present their work. It took a number of years of diplomacy and many hours and days of arguing and persuasion, until the GCS was reformed into a modern scientific society similar to the scientific branch of the AHA. The anonymization of submitted abstracts prior to evaluation for acceptance for presentation met major resistance. The rapid increase in the number of oral and poster presentations generated a general fear of loss of quality, the introduction of parallel sessions the fear of loss of control.

The success of the new generation of German basic and clinical scientists on both the European and International levels with respect to number and quality of presentations at meetings provided evidence that the reorganization of the GCS in the 1970s by Professor Schaper was the right decision about providing the opportunity for young scientists to present their data on their home base. Professor Schaper's contributions to the organization of the German society culminated in his presidency of the GCS during 1995. The year before, he was president of the annual meeting of the European Society of Cardiology in Berlin.

At the Max Planck Institute, it was his genuine curiosity in research and his high threshold against uncritical acceptance of so-called current opinions that frequently made Professor Schaper successful in his work and also made him a role model for young researchers. He is remembered saying: "If you have a preparation that does not work at all for you, while it seems to work for others, stay with your task, double check every step, you might be after something interesting." He seemed to see his role in the institute in thinking more and profoundly than others, while giving support to his fellows. He was always interested in their work; however, sometimes it was hard for them to know what he thought of it. When his advice was sought, troubled by doubts about the progress of a project, he might say, "stop talking-start working." He was extremely loyal to coworkers who stayed for a long time on his team and youngsters, who used his institute as a "spring board" for their own scientific career, and frequently excelled in their work in a few years.

His leadership style was characterized by nonverbal communication rather than by preaching. His work ethics, his personal discipline, not only in his intellectual approach to his work and as a consequence, in the practical follow-through, have all been exemplary and definitely influenced those around him.

His interest in clinical science and transfer of basic scientific work into clinical practice was also possibly nurtured over the years by the close vicinity of the clinical cardiovascular center, which is part of the Max Planck complex in Bad Nauheim. As a lecturer at the Department of Physiology, University of Gießen he had continuous contact with students and more so as an advisor to graduate students, who were working on their thesis at his institute. Both may have stimulated his continuous efforts in reforming the GCS in order to provide a national platform for young scientists of basic and clinical provenience.

In addition, his physical fitness is legend: at an age, when most German intellectuals seemed to have less interest in physical fitness, he was competing successfully in bicycle races and ski marathons. He might have looked somewhat drained after such weekends, but he would never talk of these events at work. However, if someone felt strong enough, he was allowed to join him for his daily morning runs in the park of Bad Nauheim, in winter before dawn.

Another unique special feature at the institute was the "Professor Schaper double pack": Two successful scientists at eye level, who lived a successful marriage, in mutual trust and who obviously enjoyed the added value of each other in their work and their lives, who raised three healthy, successful children and fed a very friendly dog. In hindsight, all of them may have contributed to a very successful life.

Professor Schaper's honors include the Order of Merit of the German Republic in 2005 and a very long list of national and international scientific awards. We can in no way list them all here. His 
position is best described by an anecdote from a session of the nominating committee for awards, who was honoring Professor Schaper for his merits on behalf of the German Cardiac Society. The conclusion was: He has everything. The one thing left was the Honorary Membership of the GCS, which he received in 2001.

We are grateful to Wolfgang Schaper for his support as a mentor, and we wish him all the best on the occasion of his 75th birthday.
Kerstin Boengler

Ivo Buschmann

Elisabeth Deindl

Martin Gottwik

Hans Martin Hoffmeister

Wulf Ito

Hermann Klein

Manfred Mauser

Christoph Nienaber

Vera Regitz-Zagrosek

Stefan Sack 